\title{
KRŪTIES VĖŽIU SERGANČIŲ PACIENČIUU POTRAUMINIO STRESO SUTRIKIMO SOCIODEMOGRAFINIAI IR KLINIKINIAI RIZIKOS VEIKSNIAI BEI METŲ DINAMIKA
}

\author{
Jurgita Kazlauskiene் ${ }^{1}$, Giedrė Bulotiené $\dot{e}^{2,3}$, Natalja Fatkulina ${ }^{3}$ \\ ${ }^{1}$ Vilniaus kolegija, ${ }^{2}$ Nacionalinis véžio institutas, \\ ${ }^{3}$ Vilniaus universiteto Medicinos fakulteto Sveikatos mokslu institutas
}

Raktažodžiai: potrauminio streso sutrikimas, krūties vėžys, rizikos veiksniai.

\begin{abstract}
Santrauka
Krūties vėžio diagnozę sužinojusios moterys patiria stiprų sukrètimą, kuris gali paveikti daugeli gyvenimo sričių ir stipriai sutrikdyti pacienčių adaptaciją. Krūties vėžiu sergančių pacienčių potrauminio streso sutrikimo rizika yra didesne, nei bendrojoje populiacijoje. Tyrimo tikslas - įvertinti sociodemografinių ir klinikinių veiksnių įtaką potrauminio streso sutrikimo rizikai prieš krūties operaciją ir praejus vieneriems metams po jos. Tyrimo rezultatai parodè, kad krūties vèžiu sergančių pacienčių potrauminio streso sutrikimo rizika per metus statistiškai reikšmingai sumažèjo. Potrauminio streso sutrikimo riziką praejjus vieneriems metams po operacijos didina gyvenimas santuokoje arba partnerysteje ir aukštesnis išsilavinimas. Apmokamas darbas kelia potrauminio streso sutrikimo riziką prieš operaciją, bet apsaugo nuo šios rizikos praejus vieneriems metams po operacijos. Trumpas laiko tarpas po naviko nustatymo didina potrauminio streso sutrikimo riziką. Krūtị tausojanti operacija, praèjus vieneriems metams po jos, kelia potrauminio streso sutrikimo riziką. Teikiant sveikatos priežiūros paslaugas krūties véžiu sergančioms pacientėms, tikslinga atkreipti dèmesi i jų psichologines problemas ir poreikius ankstyvajame (prieš operaciją) ir vèlyvajame (praejus vieneriems metams) sveikatos priežiūros paslaugų teikimo etape. Svarbu ị pacienčių sveikatos priežiūros procesą kryptingai įtraukti jų šeimos narius ir artimuosius, taip siekiant sustiprinti pagalbą bei paramą iš artimiausios pacientei socialinès aplinkos.
\end{abstract}

\section{İvadas}

Onkologinès ligos yra viena dažniausių mirtingumo priežasčių Lietuvoje ir kitose Europos Sajungos šalyse, mir- tingumo struktūroje jos užima antrąą vietą. Krūties vėžys yra labiausiai pasaulyje paplitusi moterų onkologinè liga $[1,2]$. Krūties vėžio diagnozę sužinojusios moterys patiria stiprų sukrètimą [3], kuris gali pasireikšti nerimu, kaltès jausmu, mirties baime, savivertès pokyčiais, nemiga, apetito sutrikimais ir kitais simptomais $[4,5]$. Onkologine liga paveikia visus moters gyvenimo aspektus: fizinę sveikatą, darbingumą, šeimini gyvenimą, santykius su aplinkiniais bei psichologinę savijautą [6]. Recidyvuojanti ligos eiga, ilgą laiką trunkantis gydymas, pablogejjusi gyvenimo kokybė, kūno pokyčiai, liūdesys dèl praradimų, rūpestis dèl artimujų formuoja sunkią psichologinę patirtį. Šios ligos atsiradimas gali būti vienas iš labiausiai pacientę traumuojančiu potyrių per visą jos gyvenimą [7], keliantis potrauminio streso sutrikimo (PTSS) riziką [8]. Išsivysčius šiam sutrikimui, pacientes vargina pasikartojantys košmariški sapnai, vengiama situacijų, primenančių vėží, jaučiamas bendras nerimas, panikos priepuoliai, kaltès jausmas. Šio sutrikimo atveju normali adaptacinè veikla tampa neịmanoma, pablogeja pacienčių emocinè adaptacija, socialinis funkcionavimas ir dalyvavimas gydymo procese [9]. Krūties vėžys tai ne tik sunki liga, bet ir ekstremalus psichologinis išbandymas moteriai. Onkologinès ligos pradžia gali būti staigi, nelaukta ir grésminga [10,11]. Psichologines reakcijas gali sukelti ne tik suvokta grèsmé ar klinikiniai simptomai, bet ir ilgalaikis bei nemalonus gydymas ar chirurginès procedūros [12]. Krūties vėžio, kaip ir kiekvienos sunkios somatinès ligos atveju, yra PTSS rizika. Šis sutrikimas pacientą gali varginti labiau, nei pirminè liga $[10,12]$.

PTSS yra dažnesnis tarp onkologinių pacientų nei bendrojoje populiacijoje $[8,9,13]$, todèl tyrimų, nagrinejjančių ịvairiomis onkologinèms ligoms sergančiųų PTSS, daugėja. S. Swartzman, atlikęs 11 PTSS paplitimo tyrimų analizę padarè išvadą, kad krūties véžiu sergančios pacientès dažniau patiria ši sutrikimą, nei turintieji kaklo ir galvos, priešinès liaukos ar tiesiosios žarnos navikus, tačiau rečiau, 
nei sergantieji galvos smegenų, kraujo ar gimdos vėžiu [8]. İvairių tyrimų duomenimis, PTSS paplitimas tarp krūties věžio pacienčių svyruoja nuo 5 iki 32,3 procento [14-20].

Tyrimo tikslas - ịvertinti sociodemografinių (amžiaus, šeiminès padèties, išsilavinimo, gyvenamosios vietos, užimtumo) ir klinikinių (laiko nuo naviko nustatymo, ligos stadijos, gydymo) veiksnių itaką potrauminio streso sutrikimo rizikai prieš krūties operaciją ir praejjus vieneriems metams po jos.

\section{Tyrimo medžiaga ir metodai}

Tyrimas buvo atliktas gavus Lietuvos bioetikos komiteto leidimą Nr. 158200-07-367-94. I tyrimą buvo įtrauktos moterys, sergančios T1-T3/N0-N3/M0 stadijų krūties vėžiu ir gydytos Nacionalinio vėžio instituto Krūtų chirurgijos ir onkologijos skyriuje. Itraukimo ị tyrimą kriterijai: pacienčių sutikimas dalyvauti tyrime, amžius nuo 21 iki 80 metų, suprantančios lietuvių kalbą, galinčios atsakyti ị pateiktus klausimus lietuvių kalba, anksčiau nesirgusios vėžiu, o penkerių metų laikotarpiu - depresija. Tyrimo dalyvių dar buvo prašoma pateikti duomenis apie išsilavinimą, užimtumą, šeiminę padèti, gyvenamają vietą.

Tyrime dalyvavo 421 paciente, iš kurių 188 pakartotinai užpildè klausimynus praèjus metams nuo tyrimo pradžios. PTSS rizikai matuoti buvo naudota E. Kazlausko ir kt. 2006 metais Lietuvoje adaptuota Itvykio poveikio skale (IES-R) (angl. Impact of Event Scale - Revised) [21]. IES-R bendro ịverčio ịvertinimas yra visų metodiką sudarančių teiginiu ịverčių bendras klausimyno rodiklis, kuris būdamas lygus arba didesnis už 34 rodo PTSS riziką [22-25].

Tyrimas buvo organizuojamas dviem etapais. Pirmojo etapo metu respondentėms, likus 1-2 dienoms iki krūties operacijos, buvo pateikiamas klausimynas ir specialiai šiam tyrimui sukurti klausimai apie jų socialinę padètị. Duomenys apie pacienčių amžių, diagnozę ir taikytus gydymo būdus, pacientems sutikus, buvo paimti iš jų ligų istorijų. Anketas tiriamosios pilde pačios. Antrasis tyrimo etapas vyko praejus vieneriems metams po operacijos. Jo metu tiriamosioms paštu buvo išsiųstas kreipimasis ir klausimynas jų nurodytu adresu. Moterys savarankiškai pilde klausimynus namuose ir paštu grąžindavo tyrèjui.

Statistinè duomenų analizè. PTSS rizikos ryšiui su sociodemografiniais ir klinikiniais veiksniais nustatyti naudotas logistinès regresinès analizès metodas. Modelio formavimui naudoti standartiniai metodai: Chi kvadrato $\left(\chi^{2}\right)$ reikšmingumo lygmuo (p) $<0,05$; Hosmer-Lemeshow statistikos $\mathrm{p} \geq 0,05$; koeficientų ženklai neatrodo nelogiški; teisingai klasifikuojama ne mažiau kaip 50 proc. atvejų, kai $Y=1$ ir kai $Y=0$; determinacijos koeficientas $\geq 0,20$. Galutiniam išvadų apie nepriklausomų kintamujjų ryši su priklausomu kintamuoju vertinimui apskaičiuotas šansų santykis ( $\breve{S} S$ ) ir jo 95 proc. pasikliautinieji intervalai (PI).

Neparametrinių kriterijų skirstinių lyginimui tarp nepriklausomų grupių naudoti Mann-Whitney ir Kruskal Wallis testai, tarp priklausomų - Wilcoxon ženklų-rangų ir Friedman testai. Kintamiesiems vertinti naudotas vidutinis rangas (neparametrinis aritmetinio vidurkio pakaitalas, parodantis, kuris kintamasis linkęs būti didesniu) ir rangų suma.

Ryšiai tarp požymių arba skirtumai laikyti statistiškai reikšmingais, kai p reikšmè buvo mažesnè už pasirinktaji reikšmingumo lygmenị $\alpha=0,05(\mathrm{p}<0,05)$.

\section{Tyrimo rezultatai}

Krūties vėžiu sergančių pacienčių potrauminio streso sutrikimo rizikos dažnis. IES-R klausimyno įverčiai parodè, kad PTSS riziką turejjo 44 proc. pacienčių pirmajame tyrimo etape. Po vienerių metų šio sutrikimo rizikos dažnis buvo perpus mažesnis ir sudare 22 procentus. Per metus laiko ìvyko IES klausimyno įverčių pokytis tarp krūties vėžiu sergančių pacienčių. Abiejuose tyrimo etapuose dalyvavo ir užpildè klausimyną 188 pacientės. Tyrimo dalyvių klausimyno ịverčių mediana (Mdn) variavo nuo 30,5 pirmajame iki 21 antrajame tyrimo etape. 130 tiriamujų IES-R bendras ivertis per metus sumažejo. Wilcoxon testas parodè, kad tirtų pacienčių PTSS rizika per metus sumažėjo reikšmingai $(\mathrm{Z}=-5,34 ; \mathrm{p}<0,001)$, tačiau 57 , t.y trečdaliui, PTSS rizika padidejo.

Palyginome, ar skyrèsi atskirų IES-R subskalių vertinimas abiejuose tyrimo etapuose. Frydman testas parode, kad tiek pirmajame $\left(\chi^{2}(2)=288,6 ; p<0,001\right)$, tiek antrajame $\left(\chi^{2}(2)=144,2 ; p<0,001\right)$ tyrimo etape yra statistiškai reikšmingų skirtumų tarp subskalių vertinimo. Wilcoxon testas parode, kad tiek pirmojo, tiek antrojo tyrimo etapo metu daugiausiai buvo pacienčių, kurių padidejjusio dirglumo subskalès ịverčiai buvo reikšmingai mažesni, palyginti su vengimo ir irzlumo subskalemis $(\mathrm{p}<0,001)$. Vengimo ir irzlumo subskalių ịverčiai statistiškai reikšmingai nesiskyre nei vieno etapo metu ( $>>0,05)$. Galima teigti, kad pacientėms mažiausiai būdingi padidejusio dirglumo simptomai, o invazijos ir vengimo simptomų išraiška yra panaši.

Potrauminio streso sutrikimo rizikos veiksniai prieš chirurginị krūties vèžio gydymą. Tyrème, kaip sociodemografiniai veiksniai veikia sergančiųjų krūties véžiu patiriamą potrauminį stresą prieš chirurginį naviko gydymą (1 lentelè). Logistinès regresijos modelis $\left(\chi^{2}(5, \mathrm{n}=383)=25,8 ; \mathrm{p}=0,024\right)$ parodè, kad amžius, šeiminè padètis, išsilavinimas ir gyvenamoji vieta įtakos PTSS rizikai neturejo, šansų santykis šiose grupèse buvo panašus, o esantys skirtumai statistiškai nereikšmingi. Vienintelis šiame modelyje reikšmingas veiksnys - užimtumas. Pacientès, kurios turèjo apmokamą 
darbą, patyre 1,56 karto didesnị potrauminị stresą nei tos, kurios apmokamo darbo neturejo.

Tyrimo metu analizavome, kokią reikšmę patiriamam stresui turi suplanuotos operacijos apimtis ir laikas, praejęs nuo to momento, kai krūtyje buvo diagnozuotas navikas ( 2 lentelè). Pritaikytas dvinarès logistinès regresijos modelis tiko duomenims $\left(\chi^{2}(4, n=420)=16,7 ; p=0,002\right)$. Trumpas laiko tarpas po naviko nustatymo didina tikimybę patirti PTSS. Pacientès, kurios sužinojo, kad krūtyje yra navikas prieš 4 savaites, turèjo 2 kartus didesnę tikimybę patirti PTSS simptomus, nei tos pacientès, kurios sužinojo anksčiau. Planuotos operacijos apimtis nèra reikšmingas PTSS rizikos veiksnys.

1 lentelè. Sociodemografinių veiksnių įtaka potrauminio streso sutrikimui pirmajame tyrimo etape $(\mathrm{n}=421)$

$B$ - koeficientas; S.N. - standartinis nuokrypis; Wald -Voldo kriterijus; p - reikšmingumo lygmuo; ŠS- šansų santykis; $P I$ - pasikliautinasis intervalas; $\chi^{2}$ - chi kvadrato kriterijus; $n$-tiriamuju skaičius grupèje.

\begin{tabular}{|l|l|c|c|c|c|c|c|}
\hline Veiksnys & & B & S.N. & Wald & p & ŠS & $\mathbf{9 5 \% ~ P I ~}$ \\
\hline Amžius & $\begin{array}{l}0-<55 \text { metai } \\
1-\geq 55 \text { metai }\end{array}$ & $-0,161$ & 0,239 & 0,451 & 0,502 & 0,85 & $0,53-1,36$ \\
\hline Šeiminè padėtis & $\begin{array}{l}\text { 0- viena (išsisky- } \\
\text { rusi, našlé) } \\
1-\text { ištekejjusi arba } \\
\text { ilgalaikèje partne- } \\
\text { rystejje }\end{array}$ & 0,193 & 0,218 & 0,779 & 0,377 & 1,21 & $0,79-1,86$ \\
\hline Išsilavinimas & $\begin{array}{l}0-\text { mažiau nei ba- } \\
\text { kalauras } \\
1-\text { bakalauras ir } \\
\text { daugiau }\end{array}$ & 0,025 & 0,231 & 0,012 & 0,913 & 1,03 & $0,65-1,61$ \\
\hline Gyvenamoji vieta & $\begin{array}{l}\text { - miestas } \\
1-\text { kaimas }\end{array}$ & 0,135 & 0,248 & 0,296 & 0,586 & 1,14 & $0,70-1,86$ \\
\hline Užimtumas & $\begin{array}{l}0-\text { nedirbanti ap- } \\
\text { mokamo darbo } \\
1-\text { dirbanti apmo- } \\
\text { kamą darbą }\end{array}$ & 0,443 & 0,233 & 3,614 & 0,049 & 1,56 & $0,99-2,46$ \\
\hline Konstanta & & $-0,479$ & 0,335 & 2,05 & 0,152 & 0,62 & - \\
\hline
\end{tabular}

2 lentelè. Suplanuotos operacijos apimties ir laiko nuo naviko nustatymo įtaka potrauminio streso sutrikimo rizikai pirmajame tyrimo etape $(\mathrm{n}=421)$

KTO - krütị tausojanti operacija; sav. - savaité; B - koeficientas; S.N. - standartinis nuokrypis; Wald -Voldo kriterijus; $p$ - reikšmingumo lygmuo; $\check{S} S$ - šansu santykis; PI-pasikliautinasis intervalas; $\chi^{2}$ - chi kvadrato kriterijus; $n$-tiriamuju skaičius grupèje.

\begin{tabular}{|c|c|c|c|c|c|c|c|}
\hline \multicolumn{2}{|l|}{ Veiksnys } & B & S.N. & Wald & $\mathbf{p}$ & ŠS & $95 \%$ PI \\
\hline $\begin{array}{l}\text { Operacijos } \\
\text { apimtis }\end{array}$ & $\begin{array}{l}0-\text { mastekto- } \\
\text { mija } \\
1-\text { KTO }\end{array}$ & $-0,37$ & 0,221 & 2,78 & 0,095 & 0,69 & $0,45-1,07$ \\
\hline \multirow{5}{*}{$\begin{array}{l}\text { Laikas, } \\
\text { praejęs } \\
\text { nuo naviko } \\
\text { nustatymo }\end{array}$} & & & & 15,1 & 0,002 & & \\
\hline & 1 - prieš 4 sav. & 0,85 & 0,301 & 7,90 & 0,005 & 2,33 & $1,29-4,2$ \\
\hline & $\begin{array}{l}2-\text { prieš } 4-6 \\
\text { sav. } \\
\end{array}$ & $-0,21$ & 0,304 & 0,45 & 0,500 & 0,86 & $0,45-0,48$ \\
\hline & $\begin{array}{l}3-\text { prieš } 7-12 \\
\text { sav. }\end{array}$ & 0,35 & 0,288 & 1,47 & 0,225 & 1,42 & $0,80-2,5$ \\
\hline & $\begin{array}{l}4-12 \text { sav. ir } \\
\text { vèliau } \\
\end{array}$ & - & - & - & - & - & - \\
\hline Konstanta & & $-0,174$ & 0,251 & 0,478 & 0,489 & 0,84 & \\
\hline
\end{tabular}

Potrauminio streso sutrikimo rizikos veiksniai praėjus vieneriems metams po operacijos. Tyrimo metu buvo analizuota, kaip keitèsi veiksniai, darantys įtaką PTSS atsiradimo rizikai, praejus metams nuo gydymo pradžios. Tyrème sociodemografinių veiksnių daromą ịtaką (3 lentelè). Išanalizavus logistinès regresijos modeli $\left(\chi^{2}(5, n=177)=16,7 ; p=0,005\right)$, nustatyta, kad praejus vieneriems metams nuo krūties vèžio diagnozès, pacientès, kurios gyvena santuokoje arba ilgalaikèje partnerystëje, turèjo žymiai didesnę tikimybę turèti PTSS, nei tos, kurios gyveno vienos. Pacientès, turinčios aukštaji išsilavinimą, turèjo 2,5 karto didesnę riziką patirti PTSS praejus metams po operacijos, lyginant su žemesnio išsilavinimo tiriamosiomis. Riziką didino ir apmokamo darbo neturejjimas per pastaruosius metus. Pacienčių, neturèjusių apmokamo darbo, rizika patirti PTSS buvo gerokai didesnè. Reikšmingas buvo ir išsilavinimas.

Analizavome taikyto gydymo reikšmę (4 lentelè). Tokie klinikiniai veiksniai kaip krūties vėžio stadija, hormoninis ir biologinis gydymas šiam modeliui netiko, tačiau Kruskal Wallis testas parode, kad IES-R rangai tarp pacienčių, sergančių I, II ir III stadijos vėžiu, nesiskyrè $\left(\chi^{2}(2)=0,819\right.$, $\mathrm{p}=0,66)$. Logistinès regresijos modelis $\left(\chi^{2}(3, n=188)=17,7 ; \mathrm{p}=0,001\right)$ parodè, kad tik operacijos apimtis turejo reikšmingos įtakos PTSS atsiradimo rizikai antrajame tyrimo etape. Pacientès, kurioms atlikta krūtį tausojanti operacija (KTO), turi 2,5 karto didesnę riziką patirti PTSS praejus vieneriems metams po operacijos, nei tos, kurioms atlikta mastektomija.

\section{Diskusija}

PTSS tarp onkologinių pacientų analizuojamas daug rečiau, nei depresija ar nerimas. Būdinga tai, kad moterys labiau linkusios patirti PTSS 
simptomus nei vyrai, tai gali būti susiję su lyties skirtumais, socialiniais vaidmenimis ar emociniu atsparumu ir neurobiologiniu atsaku ị traumą [26]. Vėžiu sergančių moterų PTSS pasaulyje yra ịvairus, jo dažnis varijuoja (1 lentelè). Šiuos skirtumus gali nulemti daug aspektų: skirtingu laiku atliktos apklausos, kiekvienos šalies kultūriniai, ekonominiai ir mentaliniai skirtumai bei naudojami nevienodi klausimynai. Mūsų tyrimo duomenimis, beveik kas antra moteris (44 proc.), kuriai neseniai buvo diagnozuotas krūties navikas, buvo pasiekusi kliniškai svarbią EIS-R klausimyno ribą ir riziką patirti PTSS. Po metų PTSS simptomai vargino tik penktadali pacienčių. Per metus statistiškai reikšmingai sumažejjo visų subskalių, vengimo, invazijos ir padidèjusio dirglumo įverčiai. Krūties vėžiu sergančioms moterims tiek pirmajame, tiek ir antrajame tyrimo etape mažiausiai išreikšta buvo padidejjusio dirglumo subskalè, vyravo vengimo ir invazijos skalių simptomai, kurie tarpusavyje nesiskyre ir pasireiškė vienodai.

Jaunesnis amžius yra veiksnys, didinantis tikimybę patirti PTSS, taip nustate S. Palmer su bendraautoriais [27] ir kiti mokslininkai $[13,15]$. Mūsų tyrimo metu nenustatyta amžiaus ir PTSS sąsajų nei pirmajame, nei antrajame tyrimo etape. Vienintelis sociodemografinis veiksnys, kuris buvo statistiškai reikšmingas abiejuose tyrimo etapuose, - apmokamas darbas, tačiau jei pradiniame etape jis didino riziką patirti PTSS, tai vèlyvajame - mažino. Tai galima būtų sieti su ligos pradžioje atsiradusia pacienčių baime dèl ịsipareigojimų, susijusių su darbu, todèl jų užimtumas dar labiau kèle įtampą ir stresą. Vèlesniame periode turimas darbas jau turèjo apsauginę funkciją, nes
3 lentelè. Sociodemografinių veiksnių įtaka potrauminio streso sutrikimo rizikai antrajame tyrimo etape $(\mathrm{n}=188)$

B-koeficientas; S.N. - standartinis nuokrypis; Wald-Voldo kriterijus; $p$-reikšmingumo lygmuo; ŠS- šansu santykis; PI-pasikliautinasis intervalas, $\chi^{2}$ - chi kvadrato kriterijus; $n$-tiriamuju skaičius grupejje.

\begin{tabular}{|c|c|c|c|c|c|c|c|}
\hline \multicolumn{2}{|l|}{ Veiksnys } & B & S.N. & Wald & $\mathbf{p}$ & ŠS & $95 \%$ PI \\
\hline Amžius & $\begin{array}{l}0-<55 \text { metai } \\
1-\geq 55 \text { metai }\end{array}$ & $-0,863$ & 0,516 & 2,798 & 0,094 & 0,42 & $0,15-1,16$ \\
\hline $\begin{array}{l}\text { Šeiminè } \\
\text { padètis }\end{array}$ & $\begin{array}{l}0-\text { vieniša (išsiskyrusi, } \\
\text { našlè) } \\
1-\text { ištekejjusi arba ilga- } \\
\text { laikejje partnerystejje }\end{array}$ & 1,269 & 0,525 & 5,850 & 0,016 & 3,56 & $1,27-9,95$ \\
\hline $\begin{array}{l}\text { Išsilavini- } \\
\text { mas }\end{array}$ & $\begin{array}{l}0-\text { mažiau nei baka- } \\
\text { lauras } \\
1-\text { bakalauras ir dau- } \\
\text { giau }\end{array}$ & 0,921 & 0,481 & 3,664 & 0,05 & 2,51 & $0,99-6,45$ \\
\hline $\begin{array}{l}\text { Gyvena- } \\
\text { moji vieta }\end{array}$ & $\begin{array}{l}0-\text { miestas } \\
1-\text { kaimas }\end{array}$ & $-0,437$ & 0,484 & 0,819 & 0,366 & 0,65 & $0,25-1,67$ \\
\hline $\begin{array}{l}\text { Užimtumas } \\
\text { per pas- } \\
\text { taruosius } \\
\text { metus }\end{array}$ & $\begin{array}{l}0-\text { nedirbo apmokamo } \\
\text { darbo } \\
1-\text { dirbo apmokamą } \\
\text { darbą }\end{array}$ & $-1,824$ & 0,604 & 9,134 & 0,003 & 0,16 & $0,05-0,53$ \\
\hline Konstanta & & $-0,814$ & 0,705 & 1,334 & 0,248 & 0,44 & \\
\hline
\end{tabular}

4 lentelė. Taikyto gydymo įtaka potrauminio streso sutrikimo rizikai antrajame tyrimo etape $(\mathrm{n}=188)$

KTO - krūtị tausojanti operacija; B - koeficientas; S.N. - standartinis nuokrypis; Wald-Voldo kriterijus; $p$ - reikšmingumo lygmuo; ŠS- sansu santykis; PI - pasikliautinasis intervalas, $\chi^{2}-$ chi kvadrato kriterijus; $n$ - tiriamuju skaičius grupeje.

\begin{tabular}{|l|l|c|c|c|c|c|c|}
\hline Veiksnys & B & S.N. & Wald & p & ŠS & $\mathbf{9 5 \% ~ P I ~}$ \\
\hline $\begin{array}{l}\text { Operacijos ap- } \\
\text { imtis }\end{array}$ & $\begin{array}{l}0-\text { mastekto- } \\
\text { mija } \\
1-\text { KTO }\end{array}$ & 0,739 & 0,770 & 5,104 & 0,024 & 2,69 & $1,26-12,8$ \\
\hline Chemoterapija & $\begin{array}{l}0-\text { netaikyta } \\
1-\text { taikyta }\end{array}$ & $-0,588$ & 0,373 & 2,493 & 0,114 & 0,56 & $0,27-1,15$ \\
\hline $\begin{array}{l}\text { Spindulinis gy- } \\
\text { dymas }\end{array}$ & $\begin{array}{l}0-\text { netaikyta } \\
1-\text { taikyta }\end{array}$ & 0,605 & 0,397 & 2,316 & 0,128 & 1,83 & $0,84-3,99$ \\
\hline Konstanta & & $-2,789$ & 0,768 & 13,190 & 0,001 & 0,06 & \\
\hline
\end{tabular}

užimtumas didino socializaciją, savirealizaciją ir padejjo užsimiršti.

Kiti 2 sociodemografiniai veiksniai, darę įtaką PTSS atsirasti, buvo šeiminè padètis ir išsilavinimas, bet tik praejjus vieneriems metams. Gyvenimas partnerystejje didino riziką susirgti PTSS. Daug mokslininkų yra vertinę tarpasmeninių santykių itaką stresui, tačiau daugeliu atvejų šio veiksnio įtakos vėlyvajam stresui nenustatė [28]. Šeimoje gali būti pareigos ir suvaržymai [29], o atsiradusi liga sukelia naujas problemas ir sunkumus, atsiranda pokyčiu poreikis.

Auštojo išsilavinimo ịtaką PTSS rizikai analizavo daug mokslininkų [16,30,31], tačiau ne visų tyrimų metu buvo nustatytas ryšys. Mūsų tyrimo metu nustatyta, kad aukštesnis išsilavinimas lemia didesnę PTSS riziką vẻlesniu gydymo periodu. Vokietijoje atlikto tyrimo metu tarp moterų, sergančių krūties vėžiu, taip pat buvo nustatyta aukštojo išsilavinimo reikšmè atsirasti PTSS [30].

Pacientės žinojo, kokios apimties operaciją ketinama atlikti, tačiau tai neturejjo įtakos PTSS atsirasti, o praejjus vieneriems metams po operacijos, šis veiksnys tapo reikšmingas. KTO didino PTSS riziką labiau, nei atlikta mastektomija. Tai galèjo 
sukelti baimè ir abejonè, ar pavyko pašalinti visą naviką, ar neliko piktybinių ląstelių, didinančių recidyvo riziką. Taikytas chemoterapinis ir spindulinis gydymas nebuvo reikšmingi. IES-R įverčių skirtumo tarp I, II ir III stadijos krūties vėžiu sergančių pacienčių nenustatyta. Tai patvirtina Sharon A. Cook su bendraautoriais gautus rezultatus, kad klinikiniai veiksniai nedažnai daro įtaką PTSS [32]. Taivano slaugytojų tyrimas parodè, kad metastazavęs krūties vėžys didina PTSS galimybę [16]. Tai patvirtino ir Danijos mokslininkai [19]. Tyrème, kaip PTSS rizika priklausè nuo laiko iki operacijos. Sunkiausias laikas moterims - pirmasis mėnuo po naviko nustatymo. Jo metu PTSS rizika yra gerokai didesnè, nei vèlesniu laiku. Tai pavojingas metas, nes dažniausiai tuo metu pacientės yra šeimos ir kitos socialinès aplinkos, bet ne medikų ar profesionalų apsuptyje.

Analizuojant atskirų IES-R teiginių dinamiką matoma, kad dauguma (15 iš 21 ) jų rodo teigimą pokytị, t. y. jų rangai per metus reikšmingai sumažèjo. Ryškiausias pokytis stebimas teiginiuose „Užplūsdavo stiprūs, su tuo susiję, jausmai“ ir „Būdavo sunku užmigti“. Klinikinèje praktikoje aktualus bendravimas ir geras kontaktas su pacientu, leidžiantis jam išsisakyti, pasidalinti emocijomis, tačiau teiginyje „Stengiausi apie tai nekalbèti“ pokyčio nebuvo. Pacientès įvardijo šią problemą esant tiek pirmajame, tiek ir antrajame tyrimo etape. Verta paiminèti, kad šio klausimo įverčiai yra didesni tarp tụ pacienčių, kurios antrajame tyrimo etape nedalyvavo. Galima daryti prielaidą, kad krūties vėžiu sergančios pacientès gali turèti ilgalaikių ir kliniškai reikšmingų bendravimo problemų su sveikatos priežiūros specialistais ir su artimaisiais.

\section{Išvados}

1. Potrauminio streso sutrikimo rizika per metus statistiškai reikšmingai sumažejo.

2. Sociodemografiniai ir klinikiniai veiksniai, darantys ịtaką krūties véžiu sergančių pacienčių potrauminio streso sutrikimo rizikai:

2.1. gyvenimas santuokoje arba partnerysteje, aukštesnis išsilavinimas didina potrauminio streso sutrikimo riziką praejus vieneriems metams po operacijos;

2.2. apmokamas darbas didina potrauminio streso sutrikimo riziką prieš operaciją, bet apsaugo nuo šios rizikos, praejus vieneriems metams po operacijos;

2.3. trumpas laiko tarpas po naviko nustatymo didina potrauminio streso sutrikimo riziką;

2.4. krūtị tausojanti operacija didina potrauminio streso sutrikimo riziką praejus vieneriems metams po operacijos.

\section{Literatūra}

1. World Health Organization. Cancer. 2021. http://www.who. int/cancer/en/
2. Gudavičienė D., Steponavičienė L., Lachej N. Krūties vėžys Lietuvoje. Acta medica Lituanica 2015;22(3):150-160.

https://doi.org/10.6001/actamedica.v22i3.3198

3. Ng CG, Mohamed S, Kaur K, Sulaiman AH, Zainal NZ, Taib NA, et al. Perceived distress and its association with depression and anxiety in breast cancer patients. PLoS One 2017;12(3):e0172975.

https://doi.org/10.1371/journal.pone.0172975

4. Triberti S, Savioni L, Sebri V, Pravettoni G. eHealth for improving quality of life in breast cancer patients: A systematic review. Cancer Treat Rev 2019;74:1-14.

https://doi.org/10.1016/j.ctrv.2019.01.003

5. Slowik AJ, Jablonski MJ, Michalowska-Kaczmarczyk AM, Jach R. Evaluation of quality of life in women with breast cancer, with particular emphasis on sexual satisfaction, future perspectives and body image, depending on the method of surgery. Psychiatr Pol 2017;51(5):871-888.

https://doi.org/10.12740/PP/OnlineFirst/63787

6. Kołodziejczyk A, Pawłowski T. Negative body image in breast cancer patients. Advances in clinical and experimental medicine: official organ Wroclaw Medical University 2019;28(8):1137-1142.

https://doi.org/10.17219/acem/103626

7. Hahn EE, Hays RD, Kahn KL, Litwin MS, Ganz PA. Posttraumatic stress symptoms in cancer survivors: relationship to the impact of cancer scale and other associated risk factors. Psychooncology $2015 \mathrm{~J} ; 24(6)$ :643-652.

8. Swartzman S, Booth JN, Munro A, Sani F. Posttraumatic stress disorder after cancer diagnosis in adults: a meta-analysis. Depress Anxiety 2017;34(4):327-339.

https://doi.org/10.1002/da.22542

9. Nipp RD, El-Jawahri A, D'Arpino SM, Chan A, Fuh CX, Johnson PC, et al. Symptoms of posttraumatic stress disorder among hospitalized patients with cancer. Cancer 2018; 124(16):3445-3453

https://doi.org/10.1002/cncr.31576

10. Koutrouli N, Anagnostopoulos F, Potamianos G. Posttraumatic stress disorder and posttraumatic growth in breast cancer patients: a systematic review. Women Health 2012;52(5):503-516. https://doi.org/10.1080/03630242.2012.679337

11. Arnaboldi P, Riva S, Crico C, Pravettoni G. A systematic literature review exploring the prevalence of post-traumatic stress disorder and the role played by stress and traumatic stress in breast cancer diagnosis and trajectory. Breast Cancer (Dove Med Press) 2017;9:473-485.

https://doi.org/10.2147/BCTT.S111101

12. Parikh D, De Ieso P, Garvey G, Thachil T, Ramamoorthi R, Penniment M, et al. Post-traumatic stress disorder and posttraumatic growth in breast cancer patients--a systematic review. Asian Pac J Cancer Prev 2015;16(2):641-646.

https://doi.org/10.7314/APJCP.2015.16.2.641 
13. Wu X, Wang J, Cofie R, Kaminga AC, Liu A. Prevalence of posttraumatic stress disorder among breast cancer patients: a meta-analysis. Iran J Public Health 2016;45(12):1533-1544.

14. Chan CMH, Ng CG, Taib NA, Wee LH, Krupat E, Meyer F. Course and predictors of post-traumatic stress disorder in a cohort of psychologically distressed patients with cancer: a 4-year follow-up study. Cancer 2018;124(2):406-416.

https://doi.org/10.1002/cncr.30980

15. Vin-Raviv N, Hillyer GC, Hershman DL, Galea S, Leoce N, Bovbjerg DH, et al. Racial disparities in posttraumatic stress after diagnosis of localized breast cancer: the BQUAL study. J Natl Cancer Inst 2013;105(8):563-572.

https://doi.org/10.1093/jnci/djt024

16. Lin YH, Kao CC, Wu SF, Hung SL, Yang HY, Tung HY. Risk factors of post-traumatic stress symptoms in patients with cancer. J Clin Nurs 2017;26(19-20):3137-3143.

https://doi.org/10.1111/jocn.13662

17. Arnaboldi P, Lucchiari C, Santoro L, Sangalli C, Luini A, Pravettoni G. PTSD symptoms as a consequence of breast cancer diagnosis: clinical implications. Springerplus 2014;3:392-392. eCollection 2014.

https://doi.org/10.1186/2193-1801-3-392

18. Elklit A, Blum A. Psychological adjustment one year after the diagnosis of breast cancer: a prototype study of delayed posttraumatic stress disorder. Br J Clin Psychol 2011;50(4):350-363. https://doi.org/10.1348/014466510X527676

19. O'Connor M, Christensen S, Jensen AB, Moller S, Zachariae R. How traumatic is breast cancer? Post-traumatic stress symptoms (PTSS) and risk factors for severe PTSS at 3 and 15 months after surgery in a nationwide cohort of Danish women treated for primary breast cancer. Br J Cancer 2011;104(3):419-426. https://doi.org/10.1038/sj.bjc.6606073

20. Naidich JB, Motta RW. PTSD-related symptoms in women with breast cancer. Journal of Psychotherapy in Independent Practice 2000; 1(1):35-54.

https://doi.org/10.1300/J288v01n01_04

21. Kazlauskas E., Gailienè D., Domanskaitè G.V., Trofimova J. Ivykio poveikio skalès - revizuotos (IES-R) lietuviškos versijos psichometrinès savybès. Psichologija 2006;2006:22-29.

https://doi.org/10.15388/Psichol.2006..4319

22. Malinauskienė V., Bernotaite L. The impact of event scale revised: psychometric properties of the Lithuanian version in a sample of employees exposed to workplace bullying. Acta medica Lituanica 2016;23(3):185-192.

https://doi.org/10.6001/actamedica.v23i3.3384

23. Creamer M, Bell R, Failla S. Psychometric properties of the impact of event scale-revised. Behaviour Research and Therapy 2003;41(12):1489-1496.

https://doi.org/10.1016/j.brat.2003.07.010

24. Weiss DS, Marmar CR. The impact of event scale - revised. In J. P Wilson \& T.M. Keane (Eds.), Assessing psychological trauma and PTSD. The Guilford Press 1997:399-411.

https://doi.org/10.1037/t12199-000

25. Civilotti C, Castelli L, Binaschi L, Cussino M, Tesio V, Di Fini G, et al. Dissociative symptomatology in cancer patients. Frontiers in psychology 2015;6:118.

https://doi.org/10.3389/fpsyg.2015.00118

26. Milad MR, Pitman RK, Ellis CB, Gold AL, Shin LM, Lasko NB, et al. Neurobiological Basis of Failure to Recall Extinction Memory in Posttraumatic Stress Disorder. Biological Psychiatry 2009;66(12):1075-1082.

https://doi.org/10.1016/j.biopsych.2009.06.026

27. Palmer SC, Kagee A, Coyne JC, DeMichele A. Experience of trauma, distress, and posttraumatic stress disorder among breast cancer patients. Psychosom Med 2004;66(2):258-264. https://doi.org/10.1097/01.psy.0000116755.71033.10

28. Cook SA, Salmon P, Dunn G, Holcombe C, Cornford P, Fisher P. A Prospective study of the association of metacognitive beliefs and processes with persistent emotional distress after diagnosis of cancer. Cognit Ther Res 2015;39:51-60.

https://doi.org/10.1007/s10608-014-9640-x

29. Swartzman S, Sani F, Munro AJ. The role of social support, family identification, and family constraints in predicting posttraumatic stress after cancer. Psychooncology 2017;26(9):1330-1335.

https://doi.org/10.1002/pon.4304

30. Voigt V, Neufeld F, Kaste J, Buhner M, Sckopke P, Wuerstlein $\mathrm{R}$, et al. Clinically assessed posttraumatic stress in patients with breast cancer during the first year after diagnosis in the prospective, longitudinal, controlled COGNICARES study. Psychooncology 2017;26(1):74-80.

https://doi.org/10.1002/pon.4102

31. Cook SA, Salmon P, Dunn G, Holcombe C, Cornford P, Fisher P. A Prospective study of the association of metacognitive beliefs and processes with persistent emotional distress after diagnosis of cancer. Cognit Ther Res 2015;39:51-60.

https://doi.org/10.1007/s10608-014-9640-x

32. Cook SA, Salmon P, Hayes G, Byrne A, Fisher PL. Predictors of emotional distress a year or more after diagnosis of cancer: a systematic review of the literature. Psycho-Oncology 2018;27(3):791-801.

https://doi.org/10.1002/pon.4601

\section{SOCIODEMOGRAPHIC AND CLINICAL RISK FACTORS AND ANNUAL DYNAMICS OF POST-TRAUMATIC STRESS DISORDERS IN BREAST CANCER PATIENTS}

J. Kazlauskienė, G. Bulotienė, N. Fatkulina factors.

Keywords: post-traumatic stress disorder, breast cancer, risk

Summary

Women who are diagnosed with breast cancer experience severe shock, which can affect many areas of their life and severely 
disrupt patients' adaptive activities. Post-traumatic stress disorder is more common in breast cancer patients than in the general population. The aim of the study was to evaluate the influence of sociodemographic (age, marital status, education, place of residence, employment) and clinical (time since tumor detection, disease stage, treatment) factors on the risk of post-traumatic stress disorder before breast surgery and one year later. The results of the study showed that the risk of post-traumatic stress disorder in breast cancer patients decreased statistically significantly over the year. Life in a marriage or partnership and higher education increase the risk of post-traumatic stress disorder one year after surgery. Paid work, on the one hand, carries a risk of post-traumatic stress disorder before surgery, on the other hand, has a protective effect against the risk of post-traumatic stress disorder one year after surgery. The short period after tumor detection increases the risk of post-trau- matic stress disorder. Breast-sparing surgery, one year after it, carries a risk of post-traumatic stress disorder. When providing healthcare to breast cancer patients, it is appropriate to pay attention to the psychological problems and needs of breast cancer patients both in the early stages of healthcare provision (before surgery) and later (after one year). It is important to involve patients' family members and relatives in a targeted way in the patient health care process, in order to strengthen help and support from the social environment closest to the patient.

Correspondece to: j.kazlauskiene@spf.viko.lt

Gauta 2021-03-09 